\section{Allmennmedisin i kortversjon}

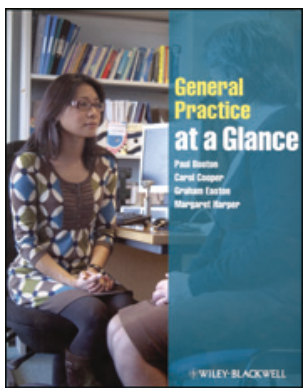

Paul Booton, Carol Cooper,

Graham Easton et al.

General practice at a glance

153 s, ill. West Sussex: Wiley-Blackwell, 2013.

Pris GBP 24

ISBN 978-0-470-65551-1

Allmennmedisin er et altomfattende lavterskeltilbud - er det overhodet mulig å lage en bok som fanger vesentligheter innen dette fagfeltet i et nøtteskall? Jeg åpnet den med en god porsjon skepsis, men ble faktisk ganske begeistret.

I hovedsak har boken en gjennomgående struktur: Hvert kapittel har to sider til disposisjon, der én side er illustrasjoner eller tabeller, og den andre siden er tekst. Illustrasjonssiden er det største ankepunktet. Teksten i illustrasjonene er ofte for omfattende, tekststørrelsen er for liten, og fonten er lite lesbar. Noen av illustrasjonene er likevel veldig gode, mens andre bare blir et forstyrrende element.

Det er to deler. Den første delen er en generell del som kalles The essence of general practice. I rask rekkefølge går forfatterne blant annet gjennom ulike temaer som anamneseopptak, behandlingsprinsipper i allmennpraksis, poenget med kontinuitet, kommunikasjon mellom første- og andrelinjetjeneste, forskning og fagutvikling, legemiddelforskrivning for barn og gamle og mishandlingsproblematikk. Alt dette skjer på ca. 20 sider. Det sier seg selv at boken ikke er utfyllende på noe felt, men den gir faktisk et godt innblikk i bredden av faget og noen essensielle sider. Som en introduksjon for medisinstudenter er den riktig bra.

Andre del omhandler vanlige problemstillinger i allmennpraksis Her er det først fem generelle kapitler om barnehelse, eldrehelse, seksualhelse, kvinnehelse og svangerskap. Her mangler bare mannehelse. Igjen gjør man ikke forsøk på å være komplett, men sider av alle disse temaene blir behandlet på en slik måte at man sitter igjen med noen hovedpunkter som er viktige. Det kan være nyttig for begynnere i faget som trenger hjelp til å skille klinten fra hveten før de har gjort seg egne erfaringer.

Deretter følger ni kapitler som er mer organspesifikke. At symptomer fra ett organ kan stamme fra andre organer er vektlagt, for eksempel at oppkast ikke nødvendigvis hører til mage-tarmarenaen. Røde flagg markerer symptomer og tegn som man skal være spesielt oppmerksom på. Som med illustrasjonene fungerer dette litt variabelt. En god del av de røde flaggene er viktige påminnelser om faresignaler som man ikke kan/bør/skal glemme. Noen ganger blir det så mange røde flagg at det ikke er godt å si hvor farlig det egentlig kan bli. En styrke er likevel at man unngår klassiske feilskjær som man noen ganger kan få fra spesialistlitteraturen av typen «hodepine er hjernesvulst til det motsatte er bevist».

Forfatterne har utvilsomt sine bein godt plantet i den allmennmedisinske hverdagen. Igjen er det hovedprinsippene som formidles. For fordypning og detaljer må man videre til annen litteratur.

Målgruppen er medisinstudenter. Den erstatter på ingen måte Hunskårs lærebok Allmennmedisin, som kom i ny utgave i år. Men den kan være nyttig å ha stående for praksislærere i allmennmedisin, slik at studenter kan kaste et blikk i utvalgte kapitler i løpet av utplasseringsperioden. Studenter som vurderer allmennmedisin som sitt fremtidige virke, vil også ha glede av å kjøpe den.

\section{Lærebok i basal reproduksjonsbiologi}

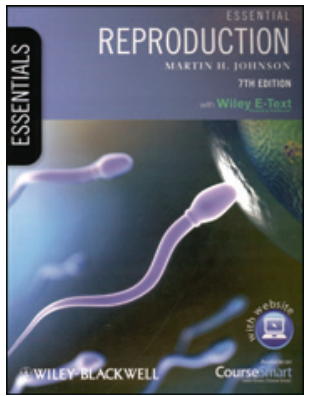

\author{
Martin H. Johnson \\ Essential reproduction
}

380 s, tab, ill. Chichester: Wiley-Blackwell,

2013. Pris GBP 45

ISBN 978-1-4443-3575-0

Dette er sjuende utgave av en lærebok om reproduksjon. Forfatteren er professor i «Reproductive Sciences» ved University of Cambridge. Han sier i forordet at den er beregnet på medisin-, veterinær- og biologistudenter på alle nivåer. Boken har derfor mange komparative aspekter, selv om hovedvekten er lagt på human reproduksjon. Den er tilegnet sir Bob Edwards, som ble tildelt Nobelprisen i fysiologi eller medisin i 2010 for å ha utviklet prøverørsmetoden. Det er også på dette feltet forfatterens egen hovedinteresse innen forskning ligger.

Denne utgaven er omstrukturert og oppdatert. Forfatteren tar leseren gjennom reproduksjonsfysiologien fra kjønnscellenes tilblivelse, gjennom pubertet og fertilisering til fødsel og amming, og er også så vidt innom klimakteriet. Assistert befruktning og prevensjon er med. Den inneholder i tillegg en god del sosiobiologi.

Layouten er behagelig, og teksten er rikelig illustrert med svært instruktive figurer. Hvert kapittel innledes med å referere til hovedpunktene fra de foregående kapitlene og trekker opp de spørsmålene som skal drøftes i det kommende kapitlet. Kapitlene avsluttes med en liste av hovedlæringspunkter. Språket flyter lett, og pedagogisk sett er boken en nytelse. Den som har kjøpt papirutgaven, får også tilgang til å laste den ned elektronisk. Denne anmelderen satte i gang med det, men da jeg fikk opp en dialogboks som fortalte at det ville ta 45 minutter, må jeg tilstå at tålmodigheten og interessen sviktet. Den elektroniske utgaven har jeg derfor ikke sett. Det er også et gratis nettsted der man kan laste ned figurene fra boken www.essentialreproduction.com. Det fungerer fint.

Mitt inntrykk er at boken særlig speiler forfatterens interesse for molekylærmedisin, men organfysiologi hos fosteret er også godt dekket. Fysiologiske forandringer hos den gravide er med, men mer summarisk. På noen felter er forfatteren ikke helt oppdatert. Når det gjelder det som denne anmelderen har god greie på, kan jeg nevne at han for eksempel holder på hypotesen om at det er en spesiell vekt (47 kg) som trigger menarke, og at han skriver at hormonspiralen skal byttes ut hvert år. De molekylærmedisinske aspektene kan jeg ikke bedømme. Det er lett å dette av lasset når det skildres hvordan en rekke faktorer og gener som heter akronymer - med bindestreker og tall - innvirker på hverandre, og jeg lurer på om det er noen andre enn de helt spesielt interesserte som egentlig klarer å henge med.

Som lærebok for medisinstudenter er denne altfor omfattende. Den inneholder også mer stoff enn det som forventes at spesialistkandidater i fødselshjelp og kvinnesykdommer skal tilegne seg. Men for den som er spesielt interessert i reproduksjonsbiologi, er dette en meget god lærebok.

Britt-Ingjerd Nesheim

Institutt for klinisk medisin

Universitetet i Oslo

Guri Rørtveit

Allmennmedisinsk forskningsenhet i Bergen

Uni helse 